\title{
IJPHN
}

\section{Do bagASI Change the Exclusive Breastfeeding Knowledge and Attitudes?}

\author{
Wido Gamani ${ }^{1}$, Laras Sitoayu ${ }^{2}$, Rachmanida Nuzrina ${ }^{2}$, Lintang Purwara Dewanti ${ }^{1}$, Anugrah \\ Novianti $^{1}$
}

${ }^{1}$ Nutritional Science Study Program, Faculty of Health Science, Universitas Esa Unggul. Jl. Arjuna Utara No. 9 Duri Kepa, Kebon Jeruk, Jakarta Barat, DKI Jakarta, Indonesia

${ }^{2}$ Dietitian Education Program, Faculty of Health Science, Universitas Esa Unggul. J1. Arjuna Utara No. 9

Duri Kepa, Kebon Jeruk, Jakarta Barat, DKI Jakarta, Indonesia

*Corresponding Author:

Wido Gamani

E-mail: gamasan24@student.esaunggul.ac.id

Laras Sitoayu

E-mail: laras@esaunggul.ac.id

\begin{abstract}
The achievement of exclusive breastfeeding (EBF) in the world and in Indonesia is still low. One of the obstacles to EBF is that the mother works. Cooler bag is a familiar media for working mothers to provide breast milk. This research uses modified cooler bags which contain information on how to provide EBF for working mothers, called bagASI. This study aims to determine the effect of bagASI on the EBF knowledge and attitudes of working pregnant women. The research method is Quasi Experimental with Pre Test - Post Test and the number of respondents is 34 working pregnant women. Respondents were divided into 2 groups, namely the intervention group who received education using bagASI and the control group using leaflets. The Paired Sample T-test showed an effect on the level of knowledge and attitudes $(p \leq 0.05)$ in both two groups. The Independent Sample T-test found that there was a difference in knowledge $(p \leq 0.05)$ between the intervention and the control group, while in the attitude there was no difference $(p \geq 0.05)$. Providing education using bagASI can increase the EBF knowledge and attitudes of working pregnant women, so bagASI can be utilized as education tool.
\end{abstract}

Key words: Attitude, bagASI, breastfeeding, knowledge, pregnant women

\begin{abstract}
Abstrak
Capaian pemberian ASI Eksklusif di dunia dan di Indonesia masih rendah. Kendala pemberian ASI Eksklusif di antaranya adalah karena ibu bekerja. Salah satu media yang dikenal ibu bekerja untuk memberikan ASI adalah cooler bag. Penelitian ini menggunakan cooler bag yang didesain dengan penambahan informasi cara pemberian ASI Eksklusif bagi ibu bekerja pada bagian luarnya, disebut bagASI. Studi ini bertujuan untuk mengetahui pengaruh bagASI terhadap pengetahuan dan sikap ibu hamil yang bekerja. Metode penelitian adalah Quasi Experimental dengan Pre Test-Post Test Control Group Design dan jumlah responden sebanyak 34 orang ibu hamil yang bekerja. Responden dibagi menjadi 2 kelompok, yaitu kelompok intervensi dan kelompok kontrol. Kelompok intervensi mendapatkan edukasi menggunakan media bagASI dan kelompok kontrol menggunakan leaflet. Berdasarkan uji Paired Sample $T$-test menunjukkan pengaruh terhadap tingkat pengetahuan dan sikap $(p \leq 0.05)$ pada kelompok intervensi dan kelompok kontrol. Berdasarkan uji Independent Sample T-test didapatkan hasil ada perbedaan pengetahuan $(p \leq 0.05)$ antara kelompok intervensi dengan kelompok kontrol, sedangkan pada sikap tidak terdapat perbedaan antara kelompok intervensi dan kelompok kontrol ( $p \geq 0.05)$. Pemberian edukasi menggunakan bagASI dapat meningkatkan pengetahuan dan sikap ibu hamil sehingga bagASI dapat digunakan sebagai media edukasi.
\end{abstract}

Kata kunci: Sikap, bagASI, menyusui, pengetahuan, ibu hamil 


\section{Introduction}

The World Health Organization (WHO) recommends that babies get EBF for 0-6 months so that the baby's growth and development is optimal. According to the WHO in 2021, 3 out of 5 babies in the world do not receive EBF (1). Furthermore, WHO states that the percentage of infants aged 0-6 months who receive EBF is only $41 \%$. Babies who are not breastfed are susceptible to the threat of infection and malnutrition. Based on the Research and Development Agency, MoH, breastfeeding for infants aged 0-5 months in Indonesia is currently still low $(37.3 \%)(2)$.

Breastfeeding from an early age has a positive impact on both mother and baby. For babies, breastfeeding plays an important role in supporting the growth, health and survival of the baby because breast milk is rich in nutrients and antibodies, reduces the risk of digestive infections and prevents allergies (1).

One of the factors that causes mothers do not be able to provide EBF is because they have to work (3-6). Working mothers are 1.54 times more likely to not provide EBF compared to mothers who do not work (7). The period of time the mother returns to work is a critical time in determining the sustainability of EBF (8), and knowledge has a strong influence on the practice of EBF (9). Knowledge of working mothers has a significant relationship to $\operatorname{EBF}(10,11)$. This is supported by the research of (12) which states that mother's knowledge affects the decision to wean the baby too early.

One of the efforts to increase the knowledge and attitudes of pregnant women who work related to EBF is through education using a cooler bag. Cooler bag is an alternative for storing expressed breast milk (13). Cooler bags are closely related to breastfeeding mothers and are often used when expressing breastmilk at work. Cooler bags can be modified into educational media called bagASI, which is a container for storing expressed milk by adding information related to lactation management for working mothers on its outer packaging. The bagASI will be used by mothers every day, it is hoped that all the information in the BagASI will be able to increase the knowledge and attitudes of working breastfeeding mothers. Many educational media are used to increase knowledge related to $\mathrm{EBF}$, including leaflets that were able to increase knowledge related to EBF in working mothers (14). This research is in line with a research conducted by Putri who finds that there is an effect of counseling with booklet media on the attitudes of pregnant women about EBF (15). This study aims to determine the effect of bagASI on the EBF knowledge and attitudes of working pregnant women.

\section{Methods}

This research used Quasi Experimental with a pretest-posttest control group design. The samples were working pregnant women. The total sampling was about 34 of trimester III pregnant women. Respondents were divided into two groups namely the intervention group and the control group who consists of 17 people on each group. The intervention group received education using bagASI. The upper side of bagASI contains information regarding how to serve the expressed breast milk and signs of stale breast milk. The front side shows the information about EBF planning during pregnancy. The information about how to express and store breast milk is showed on the back side. The right side provides information about the indication of the baby has been breastfed sufficiently, and on the left side shows the information 
about the management of breastfeeding before work and at work. As a comparison of bagASI, respondents in the control group were given education related to lactation management using leaflets so this study could conclude which media was more effective in increasing respondents' knowledge and attitudes.

The primary data were obtained using a questionnaire consists of 30 question including knowledge and attitudes related to lactation management for working mother. The questionnaire was tested using reliability test and the value of Cronbach's Alpha was 0.913 $(>0.80)$ meant that questionnaire was valid and reliable. The research process began with a pre-test, after that the respondents on each group observed and studied the information which is provided in the education media as long as one hour at the same time. Both groups only received nutrition education related to EBF for working mothers by reading and understanding the information contained on each of the media without any counseling, lectures, and discussions. After that, a post-test was conducted to see whether or not there were changes in the knowledge and attitudes of working pregnant women regarding $\mathrm{EBF}$ strategies for working mothers.

The Paired Sample T-test was used to determine differences in knowledge and attitudes related to EBF for working mothers before and after the intervention. The Independent Sample T-test was used to determine differences in respondents' knowledge and attitudes related to EBF for working mothers between the intervention group and the control group.

\section{Results}

The characteristics studied were age, education level and employment status (Table 1). The Table 2 shows that changes in average knowledge score of EBF for intervention group in pre-test is $63.52 \pm 8.53$ and experience an average increase in score to $87.84 \pm 7.54$ after being given intervention. Meanwhile, the minimum and maximum values obtained also increase from pre-test to post-test, the minimum value in pre-test is 46.66 increase to 73.33 and the maximum value in pre-test is 80.00 increase to 100 .

The control group also experiences changes in the average knowledge value of EBF for working mothers from pretest to post-test. The average value of knowledge obtained in pre-tests is $69.4 \pm 12.7$ and increases to $77.25 \pm 12.03$ at the time of post-test. In addition, there is also an increase in the minimum and maximum values in the control group. The minimum pre-test value of 40.00 increases to 53.33 and the maximum pretest value of 86.66 increases to 93.33 at the post-test.

Based on the bivariate tests, $\mathrm{p}$-value of the intervention group is 0.0001 which indicates that there is a difference in average knowledge score between pretest and post-test after education using bagASI. While the statistical test results in the pre-test and post-test control group obtained a value of $p=0.001$ which means there is a difference in average knowledge score between pre-test and post-test after being given education leaflet. 
Table 1. Characteristics of Respondents

\begin{tabular}{lll}
\hline Characteristic of pregnant women & n & \% \\
\hline Age (years) & & \\
$17-25$ & 9 & $26.47 \%$ \\
$26-35$ & 20 & $58.82 \%$ \\
$36-45$ & 5 & $14.71 \%$ \\
Total & $\mathbf{3 4}$ & $\mathbf{1 0 0 \%}$ \\
Education & & \\
SD/MI (Elementary) & 1 & $2.94 \%$ \\
SMP/MTS (Junior High School) & 19 & $55.88 \%$ \\
SMA/MA (Senior High School) & 11 & $32.35 \%$ \\
D3 (Diploma) & 1 & $2.94 \%$ \\
S1 (Bachelor) & 2 & $5.88 \%$ \\
Total & $\mathbf{3 4}$ & $\mathbf{1 0 0 \%}$ \\
Occupation & & \\
Labor & 23 & $67.65 \%$ \\
Employees & 8 & $23.53 \%$ \\
Public Administrator & 3 & $8.82 \%$ \\
Total & $\mathbf{3 4}$ & $\mathbf{1 0 0 \%}$ \\
\hline
\end{tabular}

Table 2. Univariate results of pregnant women's knowledge score before and after bagASI and leaflet education intervention

\begin{tabular}{lcccc}
\hline \multirow{2}{*}{ Indicator } & \multicolumn{2}{c}{ Intervention Group } & \multicolumn{2}{c}{ Control Group } \\
\cline { 2 - 5 } & Pre-Test & Post-Test & Pre-Test & Post-Test \\
\hline Mean & 63.52 & 87.84 & 69.4 & 77.25 \\
Deviation Standard & 8.53 & 7.54 & 12.7 & 12.03 \\
Minimum & 46.66 & 73.33 & 40 & 53.33 \\
Maximum & 80 & 100 & 86.66 & 93.33 \\
\hline
\end{tabular}

Table 3. Bivariate analysis of knowledge score for pregnant women before and after bagASI and leaflet intervention

\begin{tabular}{lcccc}
\hline & Pre-Test & $\begin{array}{c}\text { Test Category } \\
\text { Post-Test }\end{array}$ & Gap & P Value \\
\hline Intervention Group & & & & \\
Knowledge (n=17) & $63.52 \pm 8.53$ & $87.84 \pm 7.54$ & 24.31 & $0.0001^{*}$ \\
Attitude (n=17) & $86.26 \pm 12.57$ & $96.07 \pm 4.75$ & 9.81 & $0.001^{*}$ \\
Control Group & & & & \\
Knowledge (n=17) & $69.40 \pm 12.70$ & $77.25 \pm 12,03$ & 7.84 & $0.001^{*}$ \\
Attitude (n=17) & $82.74 \pm 14.35$ & $92.15 \pm 9.2$ & 9.41 & $0.002^{*}$ \\
\hline paired sample t test significant at 5\% & & &
\end{tabular}

Table 4. Bivariate Results Post-Test Scores Knowledge and Attitudes of Pregnant Women Intervention Class and Control Class

\begin{tabular}{|c|c|c|c|c|}
\hline & \multicolumn{2}{|c|}{ Group } & \multirow{2}{*}{ Gap } & \multirow{2}{*}{$P$ Value } \\
\hline & Intervention & Control & & \\
\hline Knowledge $(\mathrm{n}=17)$ & & & & \\
\hline $\begin{array}{l}\text { Post-Test } \\
\text { Attitude }\end{array}$ & $87.84 \pm 7.54$ & $77.25 \pm 12,03$ & 10.58 & $0.004 *$ \\
\hline Post-Test $(n=17)$ & $96.07 \pm 4.75$ & $92.15 \pm 9.2$ & 3.92 & 0.128 \\
\hline
\end{tabular}

*Independent sample t test signicant at $5 \%$ 
Table 3 shows that the average value of attitude with the difference between pre-test and post-test is 9.81. Then the dependent $\mathrm{t}$-test obtained value $\mathrm{p}=0.001$ which means there is a difference in attitude of respondents between before and after intervention by providing bagASI in the intervention group. The increase in attitude scores in the intervention group is statistically meaningful. Based on the Paired Sample $\mathrm{T}$-Test, the results are $\mathrm{p}=0.002$ value which means there is a difference in attitude of respondents between before and after given intervention by providing leaflet in the control group.

Table 4 shows an increase in knowledge and attitude scores after being given interventions with bagASI and leaflet. The post-test results show that knowledge in both group is significant $(p=0.004)$, so it can be concluded that there is a difference in the influence of bagASI compared to leaflet. The average knowledge score of the intervention group is 87.8 points, higher than the score obtained by the control group (77.25). Gap value between the average knowledge score between using bagASI and leaflet is 10.58 points.

The average score of breastfeeding attitudes shows that there is no significant difference with the acquisition of $\mathrm{p}=0.128$. The average score of the intervention group is 96.07 points and the average control group score is 92.15 points with a difference of 3.92 points.

\section{Discussion}

\section{Knowledge of pregnant women before and after intervention}

The age characteristics of the respondents are dominated by the early adult age group. At this stage of age, the mother has begun to have maturity in thinking so that the mother is able to make her own decisions including the decision to provide EBF to the baby even though the mother has to keep working outside the home.

The number of respondents with junior high school graduates is the largest. The post-test average scores of respondents who graduated from junior high school is 87.27 (intervention group) and 81.66 (control group). It shows that even though the respondents only graduate from junior high school, they have good knowledge of EBF (value> $80)$.

In term of occupation, the majority of respondents are labor who spend their time from morning to evening at work. It implies that the respondents will spend more their time outside and this condition will be the main obstacle for mothers to provide EBF (8). Based on this condition, the researchers introduce bagASI which contained knowledge related to strategies for working mothers to continue to provide EBF. It is expected to increase the knowledge of pregnant women regarding tips on $\mathrm{EBF}$ for working mothers, and increase the motivation of mothers to provide EBF.

The results of paired sample $t$ test for both group shows significant differences in the results of the pre-test and post-test. The $p$ value $=0.0001$ in the intervention group indicates that there is a difference in the mean score of knowledge between pre-test and posttest after being given education using bagASI, while the control group gets $\mathrm{p}$ value $=0.001$ which means there is a difference in the average score of knowledge between pre-test and posttest after being given the leaflet. In the intervention group, an increase in the level of knowledge occurs in questions related to the function of the cooler bag with an increase of $64.70 \%$, how to express breastmilk with an increase of $58.82 \%$, and about hormones that play a role in breast milk with an increase of 
$64.70 \%$. For the control group, increased knowledge was seen in questions related to how to prepare expressed breastmilk for a baby to drink (17.64\%), questions on how to express breastmilk (17.64\%), and the question about how many times of urination for the infants who are adequately breastfed (23.52\%).

Research conducted by Marcon et al. states that there is an increase in knowledge related to EBF in new mothers who use Instagram social media (16). Furthermore, the using of leaflets, booklets, and educational videos about EBF can increase maternal knowledge (17). Another study shows that the WhatsApp media can significantly increase the EBF (18).

According to data from Table 3, the average pre-test score above 60 indicates that most respondents already know the importance of EBF. It implies that the average knowledge of the two groups is good. The initial knowledge is a good predictor of knowledge, one's prior knowledge before receiving intervention determines how high the knowledge score increases after intervention (19). The interview's result shows that respondents are active in the Mother Class program, which is facilitated by Village Midwives and Community Health Center Program Holders, which are carried out regularly every month.

The increase in the value from pretest to post-test in the intervention group is 24.32 points, while the increase in the average score of the control group is 7.85 points. It can be seen that the intervention using the bagASI has a higher score compared to the intervention using the leaflet. It can be concluded that the bagASI is 3 times better and more effective as well as easier for respondents to understand for increasing the respondents' knowledge of EBF.

\section{Attitude of pregnant women before and after intervention}

In the intervention group, it is known that an increase in attitudes is related to the respondent's decision to provide EBF and the respondents' attitude to agree to express breast milk at work. Whereas in the control group the increase occurred in the attitude to agree to express breast milk at work and related to the perception that working mothers can provide EBF to their babies. From this score, it is known that the gap value in the intervention group is 9.81 points better than the point difference in the control group, namely 9.41 points.

In the intervention group there is a significant difference in the results of pre-test and post-test with values $(\mathrm{p}=$ 0.001 ), as well as in the control group there is a significant difference between the pre-test and post-test with values $(\mathrm{p}=$ 0.002). This shows that the intervention using bagASI and leaflets can improve respondents' attitudes about EBF for working mothers. This finding was supported by research conducted by Putri suggested that there is an effect of counseling with booklet media on pregnant women's attitudes about EBF (20).

\section{Differences in knowledge and attitudes of respondents between the intervention and control groups}

According to researchers, respondents who are educated using bagASI have a higher average score compared to the scores of respondents who are educated using leaflet because bagASI attracted more interest and curiosity for pregnant women. The shape of the bagASI which resembles a bag and contains information about EBF for working mothers and is displayed in an attractive image with a very simple delivery makes it easy for pregnant women to capture the information in the 
bagASI at the time of the intervention which has an impact on increasing knowledge. The respondents who are working mother feel the bagASI is very appropriate and needed for them when it is used to store milk while working. It causes the respondents to easily accept knowledge regarding how to express breast milk and strategies for providing EBF.

Media bagASI is a viewing aid that can be used in the educational process for pregnant women, this tool stimulates the sense of sight at the time of educational processes. According to Notoatmodjo, the senses that transmit the most knowledge to the brain are the eyes (21). Human knowledge obtained through the eye is approximately 75$87 \%$ while the other $13-25 \%$ is obtained through other senses, thus the material regarding EBF conveyed through the Media bagASI can be received better and easily by respondents. Media bagASI as a visual media can improve understanding and strengthen memory, this statement is in accordance with the results of this research that there is an increase in the number of respondents who are able to correctly answer questions after intervention using bagASI media.

In this study, the bagASI media is chosen as one of the learning media / information media because this media not only provides information but can also be used as a tool for saving the expressed breast milk. The same thing was reported by Rodgers and Thorton that the media used in the learning process should be able to attract the respondent's interest and attention according to the objectives and needs and conditions of the respondent (22). The media must be able to generate confidence in respondents that they are able to absorb the information provided, and the media not only provide knowledge to respondents but also be able to generate feelings of interest and pleasure. Shariff et al. states that the concept, content, and attractive appearance in the process of delivering information can make it easier for targets to receive the message or information (23). This statement is in accordance with the conditions that occurred during the study. When bagASI media was distributed to the respondents in the intervention group, their respond seemed more enthusiastic, interested, and happy.

\section{Conclusion}

The bagASI can improve the knowledge and attitudes of the respondents and can be used as a longterm educational media. It is expected to increase the motivation of pregnant women to provide EBF even though the mother has to work outside the home. Thus, innovation on education media is a must for improving knowledge and attitudes of societies.

\section{Acknowledgment}

Appreciations are conveyed to the head of the Puskesmas, village midwives, and cadres who have given permission and helped to continue the research. Thank you also to the third trimester pregnant women in the Puskesmas Tanjung Sari who have been willing to take the time to become respondents in this study.

\section{References}

1. WHO. Breastfeeding [Internet]. 2021 [cited $2021 \mathrm{Feb} 1$ ]. Available from: who.int/healthtopics/breastfeeding\#tab=tab_1

2. Kementerian Kesehatan RI Badan Penelitian dan Pengembangan. Hasil Utama Riset Kesehatan Dasar [Internet]. Kementrian Kesehatan Republik Indonesia. Jakarta; 2018. 
Available from:

http://www.depkes.go.id/resources/do wnload/info-terkini/hasil-riskesdas2018.pdf

3. Basrowi RW, Sulistomo AB, Adi NP, Vandenplas Y. Benefits of a dedicated breastfeeding facility and support program for exclusive breastfeeding among workers in Indonesia. Pediatr Gastroenterol Hepatol Nutr. 2015;18(2):94-9.

4. Okawary O, Sugiyanto, Purwati Y. Hubungan Status Pekerjaan Ibu dengan Pemberian ASI Eksklusif di Wilayah Kerja Puskesmas Sayegan Sleman Yogyakarta [Internet]. Stikkes 'Aisyiyah. Sekolah Tinggi Ilmu Kesehatan 'Aisyiyah Yogyakarta; 2015. Available from: http://digilib.unisayogya.ac.id/199/

5. Rosyadi DW. Hubungan Antara Pengetahuan Ibu Bekerja, Jam Kerja Ibu dan Dukungan Tempat Bekerja dengan Keberhasilan Pemberian ASI Eksklusif di Wilayah Kerja Puskesmas Banyudono I. J Univ muhammadiyah Surakarta [Internet]. 2016; Available from: http://eprints.ums.ac.id/47204/28/1.NA SKAH PUBLIKASI.pdf

6. Chen J, Xin T, Gaoshan J, Li Q, Zou $\mathrm{K}$, Tan $\mathrm{S}$, et al. The association between work related factors and breastfeeding practices among Chinese working mothers: A mixed-method approach. Int Breastfeed J. 2019;14(28):1-13.

7. Sari Y. Lack of exclusive breastfeeding among working mothers in Indonesia. Natl Public Heal J. 2016;11(2):61-8.

8. Weber D, Janson A, Nolan M, Wen LM, Rissel C. Female employees' perceptions of organisational support for breastfeeding at work: Findings from an Australian health service workplace. Int Breastfeed J. 2011;6(19):1-7.
9. Handayani L, Mohd Kosnin A, Kee Jiar Y. Breastfeeding Education in Term of Knowledge and Attitude through Mother Support Group. J Educ Learn. 2012;6(1):65-72.

10. Nurhayati F, Nurlatifah S. Hubungan Pengetahuan Ibu Menyusui Tentang Pemberian ASI Perah dengan Pendidikan di Wilayah Kerja Puskesmas Cimahi Tengah. Midwife J [Internet]. 2018;4(02):11-5. Available from: https://www.neliti.com/publications/26 7045/hubungan-pengetahuan-ibumenyusui-tentang-pemberian-asiperah-dengan-pendidikan

11. Istiqomah D, Rokmah NL, Susanti M. Hubungan Pengetahuan Ibu Menyusui Dengan Perilaku Pemberian Asi Eksklusif. J Ilm Kesehat. 2016;5(9):661-9.

12. Brodribb W, Fallon A, Jackson C, Hegney D. The relationship between personal breastfeeding experience and the breastfeeding attitudes, knowledge, confidence and effectiveness of Australian GP registrars. Matern Child Nutr. 2008;4(4):264-74.

13. Mustika DN, Nurjanah S, Ulvie YNS. Identifikasi Total Bakteri dan Keasaman Air Susu Ibu Perah ( ASIP ) yang disimpan di Cooler Bag. J Gizi. 2019;8(1):28-36.

14. Utami RB, Sari USC, Yulianti E, Wardoyo S. Education for Working Mothers Uses Leaflet and Electronic Media to Increase Exclusive Breastfeeding. J Educ Health Promot. 2019;8:229.

15. Putri AF. Pentingnya Orang Dewasa Awal Menyelesaikan Tugas Perkembangannya. Indones J Sch Couns. 2019;3(2):35-40.

16. Marcon AR, Bieber M, Azad MB. Protecting, promoting, and supporting breastfeeding on Instagram. Matern Child Nutr. 2019;15(1):1-12.

17. Fadhilah N, Prabamurti PN, Indraswari 
R. Penggunaan Leaflet, Booklet dan Video untuk Tingkatkan Pengetahuan, Sikap, Keyakinan dan Niat Ibu Remaja Mengenai Pemberian Asi Eksklusif di 2 Kecamatan di Kabupaten Magelang. $\mathrm{J}$ Kesehat Masy [Internet]. 2020;8(5):700-6. Available from:

5617 / e-ISSN: 2356-3346 http://ejournal3.undip.ac.id/index.php/j km\%0APENGGUNAAN

18. Issuryanti M, Widyandana, Hapsari ED. Pengaruh Edukasi Melalui Media Whatsapp Terhadap Pengetahuan Ibu dalam Memberikan ASI Eksklusif. Universitas Gadjah Mada; 2017.

19. Oshagh M, Danaei SM, Ghahremani Y, Pajuhi N, Boushehri SG. Impact of an educational leaflet on parents' knowledge and awareness of children ' $s$ orthodontic problems in Shiraz. East Mediteranean Heal J. 2011;17(2):121-
125.

20. Putri RC. Penaruh Penyuluhan dengan Media Booklet Terhadap Pengetahuan dan Sikap Ibu Hamil Tentang ASI Eksklusif di Wilayah Binaan Puskesmas Baki Kabupaten Sukoharjo. Universitas Muhammadiyah Surakarta; 2019.

21. Notoatmodjo S. Promosi Kesehatan Teori dan Aplikasinya. 1st ed. Jakarta: Rineka Cipta; 2010.

22. Rodgers DL, Withrow-Thorton BJ. The Effect of Intructional Media on Learner Motivation. Int J Instr Media. 2005;4:333.

23. Arimurti DI. Pengaruh Pemberian Komik Pendidikan Gizi Seimbang Terhadap Pengetahuan Gizi Siswa Kelas V SDN Sukasari 4 Kota Tangerang Tahun 2012. 2012. 